\title{
Corpo e experiência no processo criativo de frida kahlo: Conexões entre dança e cultura visual
}

Body and experience in the creative process of frida kahlo:

Connections between dance and visual culture

Odailso Berte

Universidade Federal de Santa Maria

\section{Resumo}

Este estudo enfatiza as questões do corpo e da experiência no processo criativo da pintora Frida Kahlo, em conexão com um processo criativo de dança baseado em imagens dessa artista. Através de entrelaçamentos entre os campos da dança e da cultura visual, o autor reflete sobre a dança contempop, uma proposição de dança baseada nas relações dos corpos com imagens popularizadas em diferentes âmbitos culturais. Dessas reflexões e práticas artísticas emergem possibilidades de fazeres críticos, criativos e performativos para o ensino, a pesquisa e a criação artística na era contemporânea da reprodução e propagação massiva de imagens.

Palavras chave: processo criativo, Frida Kahlo, corpo, imagem, dança contempop.

\begin{abstract}
This study emphasizes the issues of body and experience in the creative process of painter Frida Kahlo, in connection with a creative process in dance, based on images by this artist. Through interlacings between the fields of dance and visual culture, the author reflects about contempop dance, a dance proposition based on relations among bodies and images, popularized in different cultural spheres. From these reflections and artistic practices, possibilities for critical, creative and performative actions emerge for teaching, research and artistic creation in the contemporary era of mass reproduction and propagation of images.
\end{abstract}

Keywords: creative process, Frida Kahlo, body, image, contempop dance.

As relações entre corpo e imagem têm me instigado, de modo mais sistematizado, desde a pesquisa feita durante o Doutorado em Arte e Cultura Visual (UFG), entre os anos de 2011 e 2014. Neste artigo dou prosseguimento aos

Revista Digital do LAV - Santa Maria - vol. 9, n. 3, p. 60 - 85 - set./dez. 2016 ISSN 1983 - 7348 http://dx.doi.org/10.5902/1983734824044 
cruzamentos entre as áreas da dança e da cultura visual, centrando a reflexão no processo criativo da pintora mexicana Frida Kahlo (1907-1954) e em como este me move na articulação de processos criativos de dança. Uma importante ênfase do campo de estudos da cultura visual (MARTINS; TOURINHO, 2015) é a relação dos sujeitos com as imagens, sem quaisquer hierarquias entre imagens da arte, da mídia, de propaganda ou outros meios e suportes. Dessas friç̧ões surgiu a proposição da dança contempop (BERTÉ, 2015), atrelamento de dança contemporânea e cultura pop baseado na relação entre corpos e imagens. Frida Kahlo tanto contribui para a articulação dos procedimentos criativos da dança contempop, com seus modos de fazer arte com suas experiências, como fornece um conjunto de imagens usadas em um determinado processo de criação de dança que será analisado na segunda parte desta reflexão.

A afeição por Frida Kahlo tem crescido em minha trajetória durante os últimos quinze anos. Conheci a referida pintora pelo filme Frida (USA, 2002), dirigido por Julie Taymor e protagonizado pela atriz Salma Hayek. Desde então, uma mistura de admiração, curiosidade e inspiração tem mobilizado fazeres de pesquisa e criação artística. Apenas em 2015 conheci outro filme sobre a pintora, Frida Naturaleza Viva (MEX, 1983), dirigido por Paul Leduc e estrelado por Ofelia Medina. Diferentes imagens, visões e interpretações que reposicionaram Frida no meu imaginário. Frida Kahlo e seu processo de criação calcado em suas experiências têm me motivado a desenvolver processos de ensino e criação de dança centrados nas experiências dos dançarinos. A criação de movimentos entendida como um modo do corpo organizar suas imagens-ideias e dá-las a ver como imagens-ações, possibilita compreender a dança enquanto forma de fazerdizer o que sente e pensa sobre o que o afeta. Em meio às imbricações corpo e imagem tenho buscado criar dança e Frida Kahlo, através dos modos como realizava seu processo criativo com atenção ao corpo e às suas experiências, é uma instigante referência.

\section{O corpo-Frida recriando suas experiências}

Em muitos de seus quadros, Frida Kahlo se pintou. O corpo em dor é uma imagem recorrente em seu trabalho. Suas experiências perpassam suas obras, declarando um modo de fazer arte que tem o corpo, em sua nua e crua realidade, como protagonista. Rico (2004, p. 23, tradução do autor) constrói sua argumentação destacando que "nas obras de Frida Kahlo encontramos a imagem do corpo que funciona como centro e mestre do espaço, a partir do qual tudo parece estar em uma inquietante dialética do eu-ao-outro". Relacionando a obra da

Revista Digital do LAV - Santa Maria - vol. 9, n. 3, p. 60 - 85 - set./dez. 2016 ISSN $1983-7348$ http://dx.doi.org/10.5902/1983734824044 
artista com a fenomenologia de Merleau-Ponty, esta autora propõe que, ao longo de quase toda a produção de Frida Kahlo, o corpo, concreto e imaginado, está presente tecendo uma trama de figuras e situações provocadoras. Por sua vez, estas despertam no espectador diferentes estados de confusão e angústia.

A "profunda consciência que a artista tem do corpo" (RICO, 2004, p. 25, tradução do autor), possibilita pensarmos em seu processo de criação artística como uma forma de enfrentamento e identificação, talvez até de sublimação de suas dores. Dores do acidente automobilístico, da sua coluna machucada, das cirurgias, da sua perna afetada pela poliomielite, dos sofrimentos amorosos de sua relação com o pintor Diego Rivera (1886-1957). Conforme analisa Monsiváis (2004, p. 18, tradução do autor), entre 1944 e 1954, Frida Kahlo fez o seu Diário, criando uma forma de "exorcismo contra a dor que declara o corpo jacente, o confinamento em hospitais e as operações, entre elas a amputação de perna esquerda em 1953". Tanto o Diário como muitas de suas pinturas podem ser vistos como "espaço de transfiguração da dor em expressividade, da rotina de sofrimento em afã criativo" (MONSIVÁIS, 2004, p. 18, tradução do autor). Uma fusão de pintura e escritura, desejo e redenção, como se com suas obras Frida Kahlo pudesse se refugiar nas imagens.

Em uma de suas poéticas declarações a Diego Rivera, em seu Diário, quase como um salmo ou cântico de amor, Frida tece uma espécie de litania do corpo:

[...] Era sede de muitos anos retida em nosso corpo. [...] Tudo cercava o milagre vegetal da paisagem de teu corpo. [...] De ti até minhas mãos, percorro todo teu corpo, e estou contigo um minuto e estou comigo um momento. [...] $\mathrm{O}$ milagre vegetal de meu corpo torna-se no teu a natureza inteira. [...] Penetro no sexo da terra inteira, o seu calor me abrasa e por todo meu corpo roça o frescor das folhas macias. [...] E nesse momento ainda repleto de sensações, as minhas mãos estão mergulhadas em laranjas, e meu corpo se sente envolvido pelos teus braços. (KAHLO, 2015, p. 202-203).

Herrera (2015) comenta acerca da ânsia de fertilidade que Frida Kahlo quase transformou numa crença religiosa, em torno da qual, tudo que vive sob o sol está interligado no fluxo do universo. No quadro Raízes (1943), é o corpo-Frida quem nutre a natureza, dá à luz uma trepadeira e assim se mostra intimamente vinculado à corrente da vida. Diego Rivera expressou que "Frida é o único exemplo na Historia da Arte de alguém que rasgou o seio e o coração para dizer a verdade biológica do que sentia neles" (LAVÍn, 2007, p. 203, tradução do autor). A verdade 
biológica destacada por Rivera está em muitas das obras de Frida Kahlo, "pelo corpóreo de suas próprias aflições", comenta Lavín (2007, p. 213).

A imagem do corpo, centro da figuração, se converte no receptáculo de toda a visibilidade. Ele é o princípio e o fim de seu universo e através de sua imagem ela modela o conjunto de suas criações como algo que forma parte de sua própria definição, como um nexo de si mesma, como uma prolongação de seu ser. (RICO, 2004, p. 27, tradução do autor).

Como enfatiza Herrera (2015, p. 276), Frida se inspirava em sua realidade para realizar suas obras e "criá-las era apenas parte de - e não mais importante do que - criar e ser Frida Kahlo". A própria pintora expressou: "Eu pintei a minha própria realidade" (HERRERA, 2015, p. 323). Esta artista possibilita interpretarmos em sua arte uma forma de apropriação da experiência vivida, ou seja, um modo de expressão artística inspirada nos acontecimentos. De modo mais específico, um fazer artístico baseado nos modos como ela percebia, interpretava e transfigurava a sua realidade em forma de pintura.

\begin{abstract}
A artista recorre a esse escrupuloso realismo como forma de expressão para transmitir, da forma mais direta possível, o drama de sua condição existencial e as paixões de sua vida de mulher. O realismo também confere um peso corporal a tudo aquilo que é parte do imaginário, corporificando e tornando visível o que é invisível. (RICO, 2004, p. 51, tradução do autor).
\end{abstract}

Podemos nos perguntar: por que Frida Kahlo adotou essa forma de realismo para expressar experiências subjetivas, sentimentos pessoais e temas populares? Essa pergunta pode surgir matizada por compreensões, um tanto dualistas, de que o realismo trata de objetividade, realidade, concretude, como se isso fosse separado de sentimentos e experiências pessoais, da subjetividade. Penso o realismo de Frida Kahlo como um realismo corponectivo (BERTÉ, 2015). Conforme Lakoff e Johson (1999, p. 95, tradução do autor), o "realismo se refere a estar em contato com o mundo de modo que isso nos permite sobreviver, florescer e atingir nossos fins. Todavia, estar em contato requer algo que toca - um corpo." A proposição desses autores destaca a indissociabilidade dos procedimentos mentais e sensoriomotores do corpo, no sentido de que a capacidade da razão e a conceituação (sistemas neurais e cognitivos) estão atrelados, dependem e emergem dos sistemas perceptivos, visual, táctil, auditivo, olfativo, gustativo e de movimento.

Revista Digital do LAV - Santa Maria - vol. 9, n. 3, p. 60 - 85 - set./dez. 2016 ISSN 1983 - 7348 http://dx.doi.org/10.5902/1983734824044 


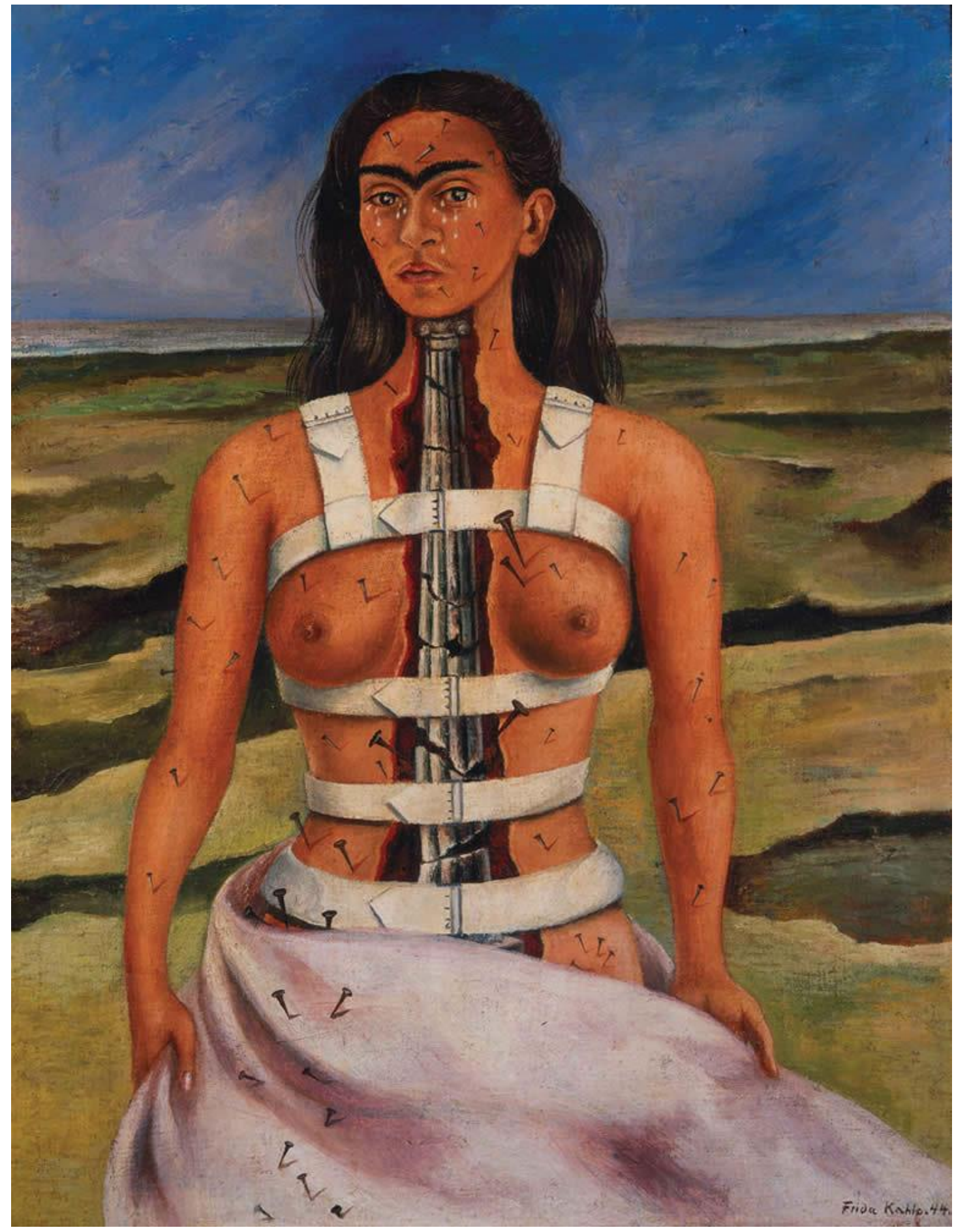

Figura 01: A Coluna Partida (1944), de Frida Kahlo, Coleção Museu Dolores Olmedo.

A Coluna Partida, figura 01, é uma das obras onde Frida Kahlo pinta o corpo seminu, em posição vertical. Corpo jovem, de curvas delineadas. Diversos pregos Ihe perfuram a pele, a carne. O colete de aço the envolve o tórax dilacerado, na função de sustentar a este e sua coluna em ruínas. Ferida exposta. Uma coluna 
jônica, ironicamente, a representação grega da beleza feminina. No rosto, as características sobrancelhas unidas que concedem à pintora uma marca identitária inconfundível. Um pranto copioso the escorre sobre o rosto. Cabelo solto, segura o tecido que the cobre o sexo e o fim do grande corte... Talvez porque ambas as fendas se fundem? A impressão que tenho é que seu olhar me fita e pergunta: está vendo? O que acha disso? Ao fundo, um horizonte azulado, uma paisagem acidentada. Um corpo destroçado e fissurado, mas em pé, mantendo a postura ereta, firme.

Vejo Frida Kahlo em A Coluna Partida, externando a destruição da coluna vertebral, órgão de grande importância na sustentação, locomoção e equilíbrio do corpo. Todavia ela segue em pé, mantendo-se no eixo vertical. De seu desejo juvenil de estudar medicina é possível que tenha brotado seu olhar anatômico, cirúrgico, botânico. Um olhar biológico perceptível em diferentes obras suas. A exuberância do corpo ferido ocupa nesta pintura o primeiro plano, expondo drama e altivez, dor e firmeza. Lavín (2007, p. 236, tradução do autor) descreve sua impressão de que Frida Kahlo travou "uma batalha de corpo inteiro, de medula e matriz, tórax e seios couraçados em corsets de couro, de gesso, de metal", para vencer a Frida frágil e dolorosa, a que amava Diego Rivera. Frida Kahlo é a sofredora dolorosa, mas, é também a rebelde que resiste, insiste na vida, revida os golpes da morte e proclama na última pintura sua, Sandías (1954): "Viva la Vida"! É a irônica moribunda que dias antes de morrer escreve a última frase em seu Diário: "Espero alegre a saída e espero não voltar jamais".

"Em imagens de si mesma descalça, sem cabeça, rachada, aberta, sangrando, ela transformava a dor nas imagens mais dramáticas possíveis, de modo a imprimir nos outros a intensidade de seu próprio sofrimento", enfatiza Herrera (2015, p. 420). A inter-relação arte, corpo e experiência é um importante aspecto que me auxilia a refletir sobre o processo criativo Frida Kahlo tendo em vista a proposição e a investigação de processos criativos em dança. A pungência com que sua vida atravessa sua arte, e vice-versa, eriça-me os sentidos produzindo diferentes formas de interpretação não centrada apenas na contemplação das obras - objetos de arte. Como seus quadros, o seu cotidiano, suas paixões, sua convalescência, seus corsets ortopédicos, seus vestidos, suas flores e enfeites são todos atraentes, persuasivos e provocadores de insinuações, significações e mitologizações. A moda Frida Kahlo, o conceito Frida Kahlo, o contexto Frida Kahlo conformam um complexo de elementos que extrapolam os limites da arte, da estética (teoria da arte), das paredes dos museus. 
Refletindo acerca das tantas imagens possíveis dessa artista e do culto cristão, nacionalista e de gênero - que a converte em santa dolorosa, símbolo da identidade mexicana e heroína feminista - também chamado de fridomania, Monsiváis (2004, p. 09, tradução do autor) diz que diante de uma foto ou um autorretrato de Frida Kahlo, mesmo um espectador pouco informado sabe de que personagem ou situação se trata: "aqui está a vida turbulenta regida pela dor física, o gênio artístico, a figura da época mítica do nacionalismo internacionalista do México, ao lado de seu marido, ou melhor, seu par, Diego Rivera". Sua imagem é icônica e disseminada mundialmente. As flores na cabeça, as sobrancelhas unidas, os vestidos de tehuana, a luta contra as enfermidades, os amores picantes e turbulentos, são detalhes de uma imagem facilmente nomeável: Frida Kahlo.

Frida Kahlo, uma mulher que "encarava com uma atitude estética o ato de se vestir" (HERRERA, 2015, p. 141), trajando-se de índia tehuana, vestimenta autóctone que ela exibe com orgulho e requinte no período histórico em que a imagem indígena era resgatada como símbolo nacionalista, em que arquétipos culturais se entrelaçam aos ideais da revolução. Ela também gostava de se vestir de modo, tradicionalmente, mais masculino, usando calças, realçando os pelos sobre os lábios (bigode), criando uma "complexa mescla de feminilidade tradicional e de rechaço a esta característica" (BARTRA, 2004, p. 53, tradução do autor). Diego Rivera pintou Frida Kahlo em alguns de seus murais; ela pintou expressivos autorretratos; o casal se aproximou e conviveu com importantes artistas norteamericanos e europeus e líderes políticos; elementos que engendraram o processo de propagação cultural de suas imagens. Como comenta Monsiváis (2004, p. 17, tradução do autor), "a fridomania é, a princípio, proposta de Frida e Diego, com o involuntário e o voluntário do caso", o que requereu a cumplicidade dos meios eletrônicos em propenso desenvolvimento. Assim germina a conjugação dos elementos da explosão mitológica que faz Frida Kahlo permanecer: a tragédia corporal que, na insistência de sobreviver a si mesma, se torna o oposto disso; a continuidade na arte e na vida; a característica de corpo único e multifacetado que adensa uma multiplicidade de imagens de si mesma.

A personagem de Frida é de uma atualidade deslumbrante porque, em sua essência, já não é só uma referência vivíssima à sua pintura (ainda que as reproduções de seus quadros sejam ubíquas) e tampouco exala o heroísmo da condição feminina. Em última instancia, Frida é o símbolo de si mesma, é o semblante no qual o espectador localiza a aparição que nada tem a ver com milagres, é o encontro dos pincéis e o amor à vida na sala de cirurgias. Frida remete à Frida, e esta criação circular a torna irrepetível. Eis aí a

Revista Digital do LAV - Santa Maria - vol. 9, n. 3, p. 60 - 85 - set./dez. 2016 ISSN $1983-7348$ http://dx.doi.org/10.5902/1983734824044 
estátua de si mesma, a filha de si mesma, a propagação dos traços únicos na era da reprodução massiva. (MONSIVÁIS, 2004, p. 29, tradução do autor).

Muitos outros artistas têm vidas curiosas, obras admiráveis e fatos pitorescos que colorem sua fama. Todavia, o fenômeno Frida Kahlo tem se tornado, numa escala aproximada de vinte anos, um fato curioso que movimenta mercados (de arte e outros artefatos) e aperta os calos de críticos ainda apegados a dogmas como durabilidade, criatividade, originalidade, autonomia, valores de estilo, forma e conteúdo da obra de arte. O corpo-Frida Kahlo, nu ou vestido, em quadros, fotos, filmes, em emblemas políticos e feministas, na capa de revistas como Vogue e Cult, em cópias de cópias de imagens, tem devastado e profanado a sacralidade da arte, adornando paredes de museus, quartos e salas de estar, casas de celebridades e de anônimos, estampando o peito de fãs, tatuando a pele de corpos aficionados.

Em sua época, Frida Kahlo era a Senhora Rivera, a esposa do grande gênio muralista Diego Rivera, afamado mundialmente. Hoje, o que vemos é "Frida em primeiro termo, e Frida e Diego em segundo lugar" (MONSIVÁIS, 2004, p. 11, tradução do autor). Lavín (2007, p. 236, tradução do autor) pergunta: "Há alguma outra figura da arte mexicana a quem chamamos por seu primeiro nome?" Convertida em um dos principais símbolos do México, ela domina as paradas da arte e da cultura pop, alcançando diversificados recantos populares, multiplicada em incontáveis formas artesanais de reprodução. Frida Kahlo pode servir de exemplo ao fenômeno da estetização cultural (AGUIRRE, 2011), o desbordamento de elementos estéticos do campo das artes para diversos âmbitos da cultura. Exposições do Brasil à Coreia do Sul, cruzando os continentes de ponta a ponta, filas e ingressos esgotados, Frida é esperada e aclamada. Em feiras de artesanato; lojas de bijuterias, roupas, calçados, acessórios, bolsas; tema de incontáveis livros e pesquisas acadêmicas, de espetáculos de dança e de teatro, de ópera, cinema e composições musicais; Frida Kahlo é moda, é cult, é kitsch, é top, é pop.

O que a torna tão prestigiada? O que a torna cobiçada por feministas, comunistas, apolíticos, artistas, artesãos, feirantes, fashionistas, hippies, punks, jornalistas, celebridades da cultura pop, acadêmicos, historiadores e críticos de arte, gays, lésbicas, transexuais, drag queens e heterossexuais? O que sua vida sofrida e, por vezes, libertina, como a de outros artistas, causa nas pessoas? O que sua obra, desprovida das técnicas artísticas tradicionais, provoca nas pessoas, desde as mais simples até os estetas que a admiram?

Ensaio uma forma simples de resposta: Frida toca. Frida e sua obra tocam afetivamente os corpos. Seu entrelaçamento de arte, corpo, experiência, de 
maneira sincera, violenta e apaixonada vincula-se de modo acessível - tangível aos amores, às dores, às aspirações e fazeres concretos de tantos de nós. Referindo-se à forma como Frida é uma pintora que nos convoca a uma esfera de intimidade para olhá-la e ver como ela nos olha, Lavín (2007) diz que, por trás da sensação de intimar que sua pintura produz, está a maneira como sensivelmente nos referimos a ela: 'Frida'. Ela hoje faz parte de uma constelação de estrelas popularizadas que, nas friç̧ões entre a reprodutibilidade técnica das imagens e a raridade da obra de arte (BENJAMIN, 2012), compõem o imaginário coletivo, são faces amigas, simbolizam sonhos, desejos e modos de vida (BERTÉ, 2015). Frida é uma imagem - amiga íntima - que habita o cotidiano cultural, adentra vidas, casas, quartos, conforma experiências, afetos e subjetividades.

Sua obra é carregada de "humor, ironia, códigos populares, de protesto e de busca de respostas sobre o sentido da existência" (LAVÍN, 2007, p. 236, tradução do autor). Esses elementos, conforme reflete a autora, denotam uma Frida doce, amável, uma Frida alegre, uma Frida que coloca no olhar daqueles a quem pinta e dela mesma, um medo diante do inevitável a seu ser perecível. A Frida sofredora e dolorosa é a Frida heroína e corajosa que, mesmo no limite da enfermidade, não recua à paixão de viver e criar realidades em forma de arte, pintando com base nas suas experiências, expressando ao mundo a potência da vida nua e crua para fazer arte; a potência da arte nua e crua para fazer vida.

A propagação da imagem, da transfiguração do corpo-Frida na contemporaneidade e as distintas formas de identificação que desperta em pessoas de diferentes contextos socioculturais, são questões complexas para se definir numa única razão. Dos modos como sua vida e obras me tocam, sim, posso falar e com estes tecer algumas reflexões. Penso que cada corpo-sujeito, a partir do seu contexto e das experiências que o formam, desenvolve modos de identificação, encontra pontos de afecção. O tema do corpo é algo que me atravessa já antes de conhecer o universo pictórico e a biografia de Frida. E eis aí um elemento que me torna propenso à identificação com sua arte. A isso se somam características e questões identitárias, políticas e de gênero. Estas identificações atravessam meu fazer-pensar e ensinar-aprender dança, tornando-me conscientemente propenso a valorizar as experiências dos corpos como potências para a criação artística.

\section{O processo criativo de Frida Kahlo}

Conforme Rico (2004, p. 24, tradução do autor), para Frida "o ato de pintar se situa no delicado limite da experiência do corpo e do mundo". Um modo de fazer artístico que, ao basear-se na realidade, não retrata factualmente a experiência e 
tampouco a transmuta de forma onírica. Muitas das obras de Frida foram inspiradas em sua realidade - conjunto de experiências, mas não são as experiências em si e sim reconstruções dessas em forma de pintura. Compreendo o realismo de Frida como ação criadora arraigada na experiência do corpo - relação corpo-ambiente com o que isso tem de interno e externo, subjetivo e objetivo, mental e sensoriomotor - indissociados, sem separação ou hierarquia. Em uma carta a Carlos Chávez, em 1939, Frida disse que, para encontrar satisfação e prazer perante os percalços da enfermidade, encontrou na pintura seu meio de expressão:

[...] meus temas sempre foram minhas sensações, meus estados de espírito e as reações profundas que vida tem causado dentro de $\operatorname{mim}[\ldots]$ materializei tudo isso em retratos de mim mesma [...] para expressar o que sentia a meu respeito e a respeito do que tinha diante de mim. (ZAMORA, 2006, p. 105).

A relação corpo e ambiente, como argumenta Greiner (2005, p.104), opera em movimento de mão dupla, não é só a cultura que influencia o corpo e tampouco apenas o corpo que influencia a cultura, pois "trata-se de uma espécie de contaminação simultânea entre dois sistemas sígnicos onde ambos trocam informações de modo a evoluir em processos, juntos". Nessas intermediações corpo e ambiente vejo o realismo de Frida, seu ato de "pintar a própria realidade". A arte de Frida "era produto de seu temperamento, vida e lugar" (HERRERA, 2015, p. 314), era sua maneira de dialogar com a realidade vivida, presenciada, experienciada. O fazer artístico de Frida, um fazer autodidata que ela não quis afiliar a nenhuma escola ou técnica tradicional, não imita as situações e acontecimentos que ela viveu. Com Hércoles (2006, p. 108) entendo que "não cabe à arte completar as lacunas da realidade, mas sim, propor outras realidades possíveis, onde as possibilidades de significação se mantenham em aberto". Frida é corpo que materializou na pintura as sensações e reações que sua realidade the causava.

Bartra (2004, p. 43, tradução do autor), propõe que "Frida Kahlo tão somente se expressava em sua pintura, e que criava nova realidade a partir de sua experiência para a arte". Tenho compreendido que nas interações corpo e ambiente ocorrem processos de troca de experiência e que aquilo que percebemos é determinado pelo que fazemos. Argumentando que a percepção é um modo do corpo pensar/explorar o mundo, Greiner (2005) propõe que ter uma experiência é confrontar-se com um modo possível do mundo. 
As experiências são frutos de nossos corpos (aparato motor e perceptual, capacidades mentais, fluxo emocional, etc.), de nossas interações com nosso ambiente através das ações de se mover, manipular objetos, comer e de nossas relações com outras pessoas dentro da nossa cultura (em termos sociais, políticos, econômicos e religiosos) e fora dela. (KATZ; GREINER, 2005, p. 132).

Ao desenvolver seu processo criativo com base em suas experiências, Frida explicita a imbricação arte, corpo e experiência que já existe independente disso ser mais ou menos explícito nas obras de arte. O realismo de Frida não é representativo, mas transformativo. A amamentação em Mi Nana y Yo (1937) e o homicídio em Unos Cuantos Piquetitos (1953), figura 02, não são fotografias jornalísticas dos fatos ocorridos. São formas de reorganização metafórica (que se referem aos fatos, mas não são eles) que Frida-corpo-artista elabora em meio aos modos como as experiências Ihe perduram, desestabilizam, arrebatam. Ao encarar suas vivências, tendo-as como referência para a criação artística, Frida as realiza de outras formas, reposicionando-as e excedendo-as.
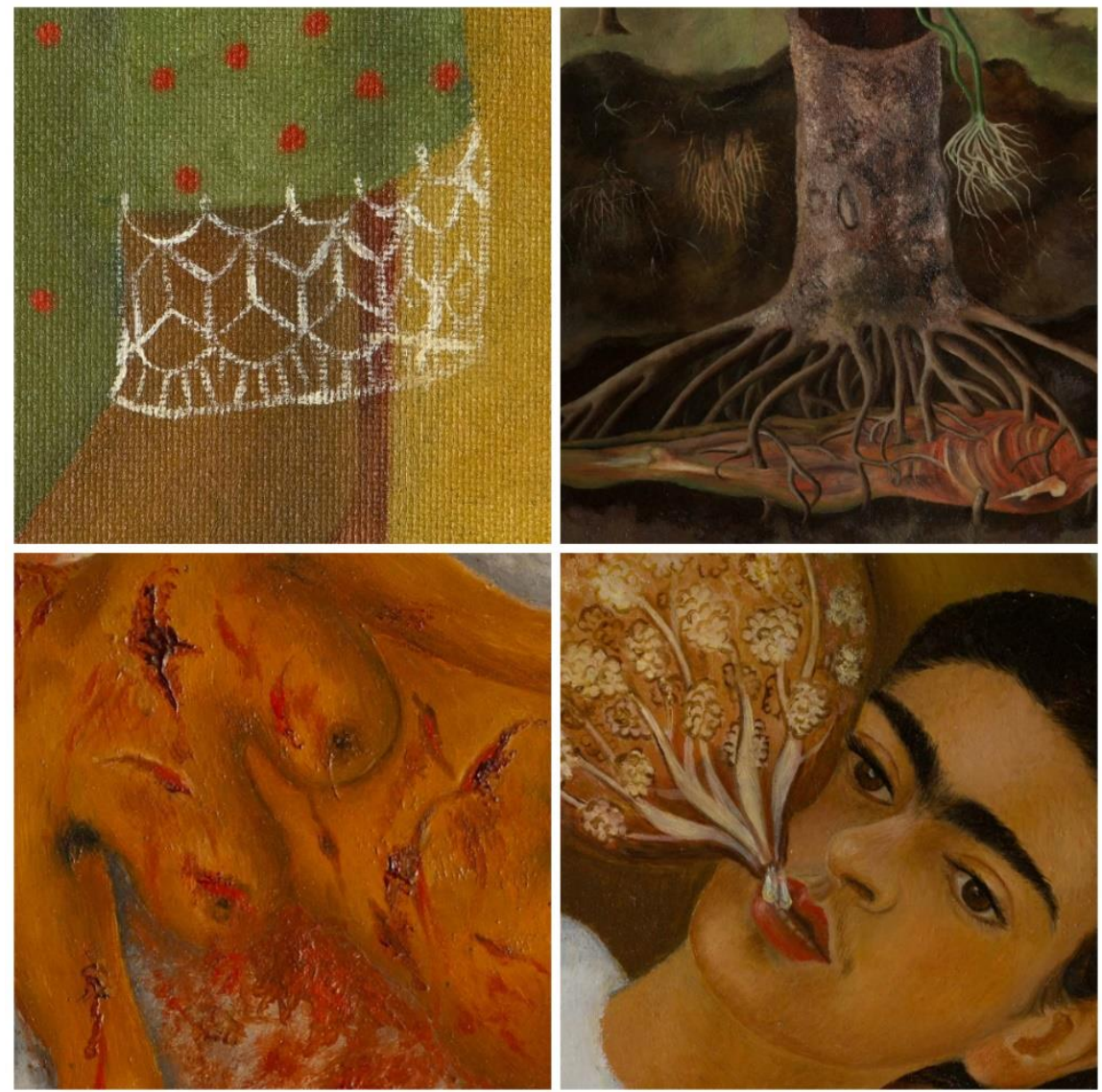

Figura 02: Detalhes das obras La niña Virginia (1929), Retrato de Luther Burbank (1932), Unos Cuantos Piquetitos (1953), Mi Nana y Yo (1937), de Frida Kahlo, Coleção Museu Dolores Olmedo.

Revista Digital do LAV - Santa Maria - vol. 9, n. 3, p. 60 - 85 - set./dez. 2016 ISSN 1983 - 7348 http://dx.doi.org/10.5902/1983734824044 
$\mathrm{Na}$ figura 02 estão detalhes de quatro pinturas de Frida. Na primeira imagem, o acabamento em renda da manga da blusa da menina Virginia. A sutileza do caimento do tecido, o modo como se molda à curvatura do braço, a finura da transparência, a delicadeza do desenho formado pela trama dos fios. Na segunda imagem, o delineamento cuidadoso das raízes, tanto as mais grossas, que transpassam o corpo, quanto as mais finas das plantas menores. A diferença acurada para as raízes de cada uma das diferentes espécies de plantas que compõem a imagem. Na terceira imagem, a crueza, a violência, a carnalidade dos cortes feitos por um punhal no corpo feminino. O sangue dos cortes maiores reluz, expressando uma vivacidade que assusta. Na quarta imagem, o olhar distante, entristecido, de tão nítido parece ter sido fotografado. O detalhamento dos pelos das sobrancelhas quase parecem penteados pelo pincel de Frida. E outros tantos detalhes que diferentes olhares poderiam ainda identificar e descrever.

Outra vez friccionando a reprodutibilidade técnica da imagem e a raridade da obra de arte, vale ressaltar que essa ampliação das imagens das pinturas de Frida, em altíssima qualidade, são um recurso facilmente encontrado e gratuitamente acessado no Google Arts \& Culture, criado em associação com diferentes Museus do mundo. Além de tours online em salas dos museus, é possível acessar obras de diferentes artistas e ampliá-las, em perfeita resolução, a ponto de detectar, com escandalosa nitidez, mínimos e inimagináveis detalhes. Nem as obras originais, pelos seus tamanhos e pela distância de visão permitida ao visitante/espectador, possibilitam uma experiência tão aproximada e com esse refinamento de detalhes. O valor de culto e exposição da obra de arte passa por mutações, ou está sendo implodido ou está tornando-se ainda mais fervoroso e avassalador no sentido de vir a nós o vosso reino através de poucos cliques.

Grande parte da riqueza do acurado detalhamento da pintura de Frida vem da condição de convalescência em que ela se encontrava e das estratégias construídas para que ela pudesse pintar. Convalescente, deitada na cama, sentada na cadeira de rodas e muitas vezes quase imobilizada pelos corsets ortopédicos, tinha cavaletes especiais para ajustar sobre a cama quando estivesse deitada ou para se adequar em frente da cadeira de rodas quando sentada. Frida pintava com a tela muito próxima de si e em sua condição, tinha um largo tempo, horas e horas para pintar. Essas situações e estratégias são condições, procedimentos, estratégias adaptativas que, interferindo no seu ato de pintar, também conformam o desenvolvimento do seu processo criativo. 
Não estou pelo labor de definir como Frida criava ou como um artista cria arte. Próximo de Greiner (2005), tento vasculhar formas de refletir sobre o quão importa a arte para a sobrevivência humana e para os estudos do corpo e, nessa perspectiva, as relações entre corpo e experiência na arte de Frida e o que isso possibilita em termos de crítica, estudo, prática, ensino e aprendizado das artes. Greiner (2005, p. 112-113) comenta sobre o reconhecimento de que "onde há arte, sempre existe um corpo, parece incontestável. O corpo pode estar lá representado figurativamente, aos pedaços, residualmente, metafórica ou iconicamente, ou seja, até mesmo como uma possibilidade e não como existente". Com a compreensão de que é da experiência que emerge a conceituação e enfatizando a necessidade de se fazer da vida um exercício político de produção sígnica e partilhamento do saber, Greiner argumenta que

- corpo artista é aquele em que aquilo que ocorre ocasionalmente como desestabilizador de todos os outros corpos (acionando o sistema límbico) vai perdurar. [...] desta experiência, necessariamente arrebatadora, nascem metáforas imediatas e complexas que serão, por sua vez, operadores de outras experiências sucessivas, prontas a desestabilizar outros contextos (corpos e ambientes) mapeados instantaneamente de modos que o risco tornar-seá inevitavelmente presente. Não à toa o sexo, a morte, o humor, a violência e todo tipo de emoção estão presentes durante estas experiências artístico-existenciais. (GREINER, 2005, p. 122-123).

As marcas autobiográficas de Frida em sua arte não delatam uma biografia descorporificada, desconexa de um ambiente (contexto sociocultural e biológico). Dos modos como as informações trocadas com seus ambientes de vida - o enredo de suas experiências - Ihe impactavam e essas (trans)formações Ihe perduravam, emergiam suas pinturas. Imagens e metáforas por vezes simples e outras complexas, diretas ou alusivas, que captam olhares e atenções, desestabilizam visões e provocam diversificadas emoções. A "estreita relação entre experiência corporal e a criação de formas e personagens" sustenta a obra de Frida expondo o "corpo" como "imagem de sua existência"; "nó de significações"; expressão das modalidades de sua vida (RICO, 2004, p. 25-29, tradução do autor). Em Frida é possível interpretarmos que as relações entre a arte e experiência corporal são intercambiáveis, permutáveis, são sistemas de um mesmo processo.

A pulsão com que as experiências de Frida perduravam-Ihe no corpo tem vida em suas obras, denotando quase uma forma de apoderarem-se dela, da tela, dos pincéis, das tintas. Suas obras excedem os fatos vividos, fazendo-se 
objetos/imagens/metáforas potentes de muitas outras significações para além das experiências a que se referem. Situações dolorosas (o acidente, as cirurgias, os abortos, a amputação da perna); pessoas de sua convivência (Diego, a família, amigos); lugares onde viveu (a Casa Azul, Coyoacán, o México, os Estados Unidos); seus animais de estimação; símbolos pré-hispânicos; e sua própria imagem são reelaborados no processo artístico.

Herrera (2015, p. 154) pontua como "a ligação pessoal entre artista e tema afetava a aparência e o significado de sua obra" e comenta como suas pinturas "ecoam seu estilo de sociabilidade, que era direto, despretensioso, espirituoso e astuto nos julgamentos que fazia das pessoas". Nos modos como ela enredava a pulsão da experiência corporal com traços, corpos e cores em seu processo criativo, convém referenciar outros aspectos como o popular, o primitivismo e o cotidiano.

A expressividade popular é como um recurso ou um tempero artístico e comunicativo que Frida usava para produzir imagens atraentes e comovedoras. Rico (2004, p. 53, tradução do autor) interpreta que, para o pensamento estético pintado por Frida, "a beleza e a poesia das coisas são encontradas nos objetos mais simples, em suas cores, na frescura de sua representação e na ingenuidade do seu traço [...] modeladas pela mão simples e direta do artesão mexicano." Essa predileção, abertamente declarada por Frida, tem raízes na sua identidade cultural, ardorosa amante da cultura, da identidade e do povo mexicanos. Em uma carta ao dr. Eloesser, um de seus médicos e amigo, Frida escreveu:

Eu não fiquei triste com a morte de Albert Bender, porque não gosto de Colecionadores de Arte, não sei por quê, mas atualmente a cada dia a arte em geral me dá menos emoção e estímulo, e acima de tudo essas pessoas que exploram o fato de serem conhecedores da arte para contar vantagem e se gabarem de terem sido "escolhidos por Deus", muitas vezes eu me dou melhor com carpinteiros, sapateiros, etc. do que esse bando de gente estúpida, os assim chamados civilizados, tagarelas, as supostas pessoas civilizadas, refinadas e cultas. (HERRERA, 2015, p. 390).

Esse comentário de Frida pode ser aliado ao seu gosto pela "cultura de la raza" e ao seu entusiasmo pelo "circo, o teatro de rua, o cinema e as lutas de boxe" (HERRERA, 2015, p. 241). Junto disso ainda soma-se o apreço às danças de salão em danceterias populares ou à dança cênica, conforme relatos de sua sobrinha Isolda Kahlo (2004). Com tais elementos é possível interpretar uma postura sociocultural e artística em vias de desapego dos maneirismos, discursos e técnicas tradicionais das artes. Para Herrera (2015, p. 272), a cuidadosa e bem elaborada 
autoimagem de Frida coincide com essa adaptação de um "estilo de arte mexicana popular" que é também "repleta de cores e alegria, e, como a vida de Kahlo, é invariavelmente teatral e sangrenta".

Herrera (2015, p. 272) comenta que "o primitivismo revela e esconde" e, nesse sentido, "o primitivismo de Frida é uma postura irônica, que Ihe permitiu a um só tempo exibir, mascarar e zombar dos tormentos íntimos". Esse estilo de arte popular tem a habilidade de modular a volúpia e a tenuidade do impacto de imagens violentas. Os modos como Frida pinta o corpo enfermo, ameaçado, sangrando, bem vestido e colorido, interligado a membros e órgãos vitais, a plantas e animais, em um conjunto de formas, cores, penas e redenções de estilo popular e primitivo, evocam as pinturas dos ex-votos que abundam nas igrejas mexicanas. Expressões populares do culto aos santos, testemunhos de feitos milagrosos onde os corpos se mostram entre o perigo de perecer e a intervenção do poder divino.

A magia da arte de Frida não é a magia de relógios derretendo. É a magia de seu anseio para que suas imagens tivessem, como ex-votos, certa eficácia: ela esperava que afetassem a vida. Frida explorava a surpresa e o enigma da experiência imediata e de sensações reais. (HERRERA, 2015, p. 314).

Junto desse impulso afetivo para que suas imagens tocassem os corpos, está o apreço pelo cotidiano, por aquilo que o corpo vive, experimenta, se relaciona em seu dia a dia, as fagulhas dos momentos. Como destaca Rico (2004, p. 58, tradução do autor), "na pintura de Frida se revela sua admiração pelo pintor do instante, do cotidiano". A maneira como Frida elaborava suas experiências e as traduzia em pinturas, fazem referência a situações de sua vida. Um simbolismo autobiográfico, simples, conecto a sentimentos, cotidiano e de trato popular. Suas referências não são anônimas ou projeções suprarreais, são experiências singulares pintadas com habilidade que contrasta o objetivo e o surreal.

"Enquanto a temática dos muralistas tendia a tornar-se retórica e estereotipada, a sua era real e concreta" (RICO, 2004, p. 63, tradução do autor). Duas posturas diferentes e complementares poder-se-ia dizer, uma centrada no coletivismo da mudança social e política dos corpos-massas, a outra na experiência concreta e singular do corpo-indivíduo. Entre essas diferenças também podemos interpretar questões de gênero dentro do campo artístico, ambiente eminentemente masculino onde prevaleciam os dogmas feitos por homens e para homens. Conforme Rico (2004, p. 63, tradução do autor), a "potência para expressar-se num lugar que não Ihe concerne", adquire em Frida "a forma de um

Revista Digital do LAV - Santa Maria - vol. 9, n. 3, p. 60 - 85 - set./dez. 2016 ISSN 1983 - 7348 http://dx.doi.org/10.5902/1983734824044 
verdadeiro grito de rebeldia ou de uma submissão incondicional". A arte de Frida resistiu brava e singelamente a essa tradição misógina. Pintar fazendo referência aos abortos, à maternidade frustrada, ao sangue, ao cotidiano, aos vestidos, ao corpo e a tantos sentimentos em torno disso, tanto pode ser visto como uma resignação às ordens do sistema visual machista, como uma revanche, uma postura de resistência que escancara a relevância do subjetivo, do corpo, do cotidiano para a vida em e da sociedade.

Numa das passagens de seu Diário, Frida se mostra inquieta em relação à sua pintura: "quero transformá-la para que seja algo útil ao movimento revolucionário comunista, pois até agora pintei somente a expressão honrada de mim mesma" (KAHLO, 2015, p. 237). Nesse momento, Frida parece referir-se ao fato de 'pintar a si mesma' como algo distante daquilo que objetiva o partido comunista, e se cobra no sentido de usar o pouco de saúde que tem para ajudar a revolução - a única e verdadeira razão de viver. Vejo sua pintura como arte que não é panfletária, não é um veículo que transporta uma mensagem ou transmite uma ideologia, não tem uma moral por trás. Sua arte e seu modo de criar não 'têm' uma mensagem, são mensagem em ato, não há subtexto além, por trás ou sobreposto.

Conforme Herrera (2015, p. 272), ao adotar o primitivismo em seu estilo e arsenal imagético, Frida reafirma "seu compromisso com a cultura nativa do México", como uma "declaração de posicionamento político esquerdista", expressando "sua solidariedade com as massas". Percebo que nos modos como Frida elaborava seu estilo de pintar, na habilidade de enredar aí suas experiências, na forma de compor sua autoimagem, ou seja, nas maneiras como estruturava seu processo criativo impregnado de primitivismo, expressão popular mexicana, cotidiano, ela já declara uma postura política e estética. E me pergunto se essa postura de um corpo-sujeito que se encara, percebe/analisa sua relação com o mundo, considera despojadamente suas experiências no ato criativo, enfrenta suas calamidades e, na ânsia da morte, grita "viva la vida", não seria uma postura revolucionária ou o ímpeto a mover toda forma de revolução?

\section{Imagens de Frida movendo corpos na criação de dança}

As afecções e experiências que a vida e obras de Frida têm me suscitado, movem processos criativos e pedagógicos em dança. A vontade e a necessidade de dançar Frida, trazer à tona e dar a ver isso que já estava à flor da pele, fazer-dizer Frida em movimentos, irrompeu com uma coreografia chamada Kahlo no Corpo (2009). Mas isso foi a ponta do iceberg... Eu-corpo afetado e (co)movido pelo 
corpo-Frida e suas imagens de sangue e flor. A mulher que pinta o corpo vestido e despido, chorando e sangrando, cativo e altivo, mobiliza-me um tipo de admiração que, em vez de deter-se na valoração de culto, busca profanar a suposta sacralidade da arte produzindo situações, vivências com outros corpos, onde as imagens são tocadas, trocadas, usadas e realizadas de outras formas. Espaços compartilhados em fazeres críticos, criativos e performativos.
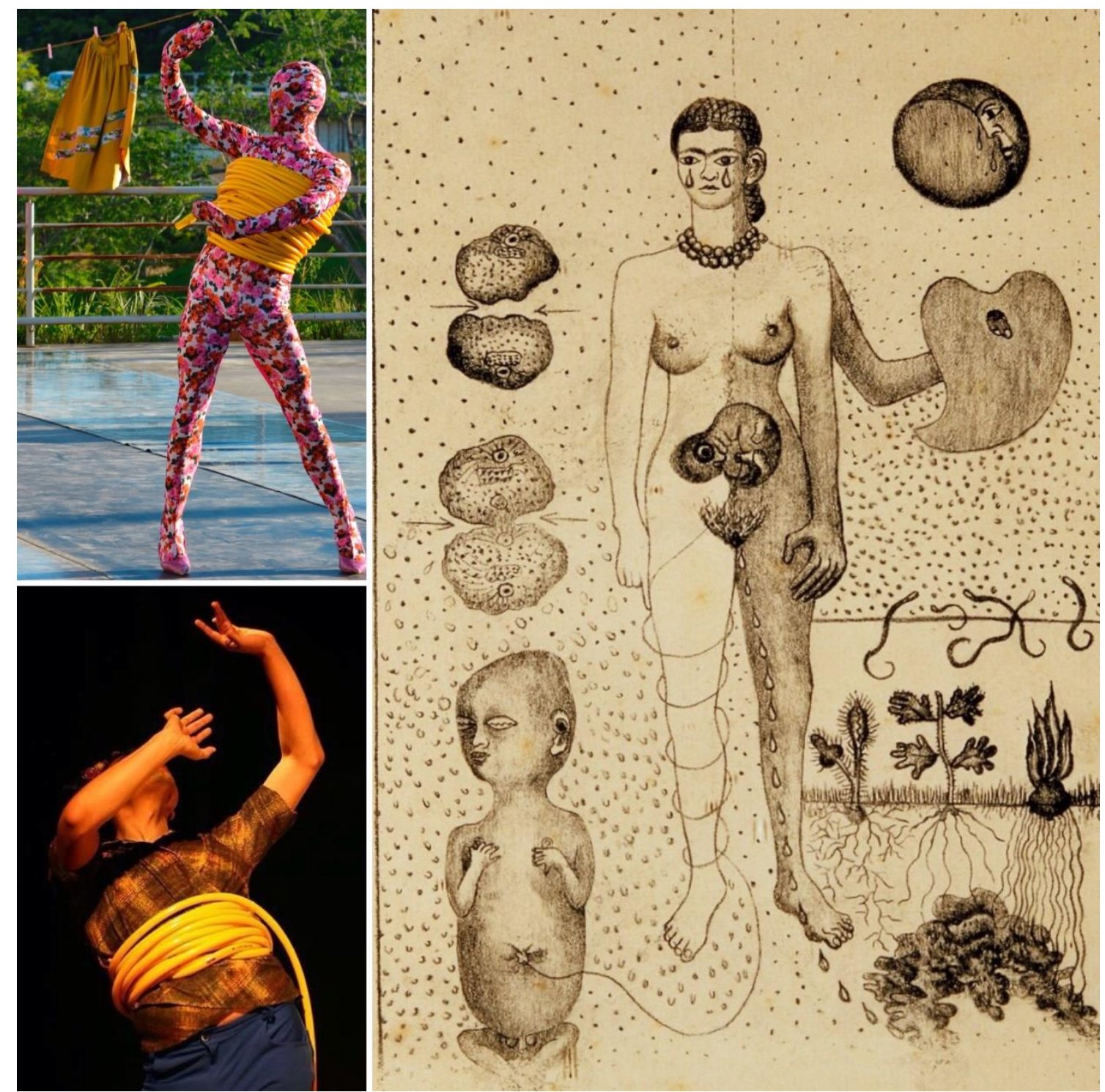

Figura 03: Dançarino Crystian Castro em cenas de FeridaCalo (2016), na parte superior, e Me Kahlo... Sashay Away (2015), na parte inferior. Fotos de Joana Günther e Patricia Cichelero. Desenho Frida y el Aborto (1932), de Frida Kahlo, Coleção Museu Dolores Olmedo. 
$\mathrm{Na}$ figura 03 estão aproximações entre fotos da intervenção de dança FeridaCalo e do experimento Me Kahlo... Sashay Away ${ }^{1}$ e o desenho Frida y el Aborto. Nesta imagem que mistura diferentes figuras, Frida se desenha dividida por uma linha pontilhada. O corpo-Frida nu tem uma metade escurecida e outra mais clara. Sua metade escurecida tem dois braços, um deles segura uma paleta em forma de coração; tem líquido (sangue? Urina?) que flui de sua vagina e parece irrigar a terra, as raízes das plantas e vermes. Também há líquido pingando de seus olhos, duas grandes gotas de lágrimas. A lua no alto também chora. Em sua metade clara, um cordão sai do feto em seu ventre, enrola-se em sua perna direita e se liga ao umbigo de outro feto ao seu lado. E outras observações ainda poderiam ser descritas.

Nas fotografias de FeridaCalo e Me Kahlo... Sashay Away, o dançarino está envolto por uma mangueira amarela. Nesta cena, ele se esmera em fazer poses e desfila usando sapatos de salto alto. $\mathrm{Na}$ sequência os demais dançarinos desenrolam bruscamente a mangueira dele, deformando suas poses. Em Me Kahlo... Sashay Away, primeiro experimento desse processo artístico, as flores cobriam o chão palco e rosto do dançarino era visível. Em FeridaCalo as flores se tornam estampa do figurino e o dançarino aparece com uma figura sem face. As cores expressivas das imagens de dança contrastam com o desenho monocromático de Frida. Há elementos que aproximam e outros que contrastam essas imagens. Vejo nas imagens do dançarino e da Frida elementos que motivam reflexões sobre questões de gênero, masculinidade, identidade, relações entre direitos da mulher, corpo e aborto, ecologia, relação corpo e ambiente, entre outras.

O processo de criação desses trabalhos de dança foi articulado de acordo com a proposição da dança contempop (BERTÉ, 2015), um entrecruzamento entre dança contemporânea e cultura pop que em seus procedimentos criativos baseia-se nas experiências dos dançarinos com imagens popularizadas em diferentes suportes e âmbitos culturais. Nesse processo, foram enfocadas imagens de Frida: reproduções de suas obras, fotografias, criações de outros artistas e sujeitos em referência às suas pinturas, imagens de filmes inspirados em sua biografia. Conforme os relatos no documentário curta-metragem Especial Interkahlos (2016), com as imagens escolhidas pelos dançarinos foram realizados atividades, jogos e

\footnotetext{
${ }^{1}$ FeridaCalo (2016) e Me Kahlo... Sashay Away (2015) são trabalhos de dança contempop, inspirados em imagens de Frida Kahlo, criados pelo Laboratório Investigativo de Criações Contemporâneas em Dança (LICCDA) do Curso de Dança - Licenciatura da Universidade Federal de Santa Maria (UFSM). O processo artístico dos referidos trabalhos é documentado no curta-metragem Especial Interkahlos (2016), disponível em: https://www.youtube.com/watch?v=NwY4q-M080M\&t=598s.
} 
exercícios de criação de movimentos e gestos que, selecionados e organizados, deram estrutura aos trabalhos artísticos.

Próximo de Frida em seu processo criativo, trabalhar com as experiências dos corpos tem sido uma estratégia de criação desenvolvida por diferentes dançarinos e coreógrafos dentro do que se tem chamado de dança contemporânea. Entre estes, tenho me interessado pelo trabalho da coreógrafa alemã Pina Bausch (1940-2009). Junto da Cia Wuppertal Tanztheater, com a qual começou a trabalhar em 1973, na cidade de Wuppertal, Alemanha, ela desenvolveu um peculiar processo de criação. Pina fazia perguntas aos dançarinos. As questões evocavam as experiências vividas por eles e os mesmos deveriam respondê-las em forma de movimentos. Com esse material de movimento emergido das experiências, a coreógrafa montava seus espetáculos.

"É bom que a dança não seja apenas uma coisa bonita, ou simpática, mas que tenha algo a ver conosco, que dê atenção aos nossos sentimentos, aos nossos desejos, às nossas aspirações, ao nosso sofrimento" (GUERREIRO, 2007, p. 69). "Eis o que faço - olhar. [...] Observar as pessoas [...] olhar as relações entre as pessoas [...] e falar sobre elas. [...] O ser humano é o modelo" (HOGHE, 1988, p. 05 e 08). Com essa forma de pensar, dita em entrevistas, a coreógrafa possibilita percebermos o seu apreço às pessoas e suas relações, às experiências e ao cotidiano para o desenvolvimento dos seus processos criativos de dança.

A proposição da dança contempop é baseada nos processos criativos de Pina Bausch e de Frida Kahlo. Nessa perspectiva o LICCDA criou os experimentos Me Kahlo... Sashay Away e Me Kahlo. A culminação dessa investigação artística, que além do processo criativo de Frida tem suas imagens como referencial disparador e dramatúrgico, dá-se com a intervenção de dança FeridaCalo (2016). Nesse trabalho artístico o propósito não é imitar, encenar ou representar as imagens. Elas são meios para acessar vivências dos dançarinos. A imagem como um potente artefato para evocar, localizar e trazer presente experiências dos corpos, as quais eles relatam em forma de movimentos, gestos e ações. Conforme a proposição da dança contempop, as imagens-artefato inspiram imagens-ideias que o corpo dá a ver em imagens-ações (BERTÉ, 2015).

Na relação corpo-imagem, cara à proposição da dança contempop, emerge a problemática da performatividade das imagens. A partir das reflexões sobre performatividade de Austin (1990), na filosofia da linguagem, e de Butler (2012), em torno dos discursos normativos que materializam sexo e gênero nos corpos, Acaso (2011) propõe a discussão sobre a performatividade visual. Esta autora enfatiza a urgência de reconhecermos

Revista Digital do LAV - Santa Maria - vol. 9, n. 3, p. 60 - 85 - set./dez. 2016 ISSN 1983 - 7348 http://dx.doi.org/10.5902/1983734824044 
o poder performativo (transformativo do social) da linguagem visual, uma mudança que nos levaria a entendêla, para além de um sistema de representação, como uma força de transformação. [...] Talvez tenhamos que escrever um texto que se chame Como fazer coisas com imagens ou As imagens fazem coisas para por em discussão o fato de que no mundo em que vivemos, a linguagem visual é o principal sistema que está transformando a realidade, performando nosso corpo, nossas ideias, nossos hábitos. É ela que nos obriga a operar-nos, a mutilar-nos, a auto torturar-nos. Longe de ser um mero instrumento de comunicação, a linguagem visual é a ferramenta que performa a realidade. E para poder refletir sobre seu poder, os museus de artes visuais (e mesmo a escola, a universidade ou qualquer outro espaço educativo) hão de começar a assumir o papel protagonista do visual na realidade externa ao museu e, portanto, hão de incorporá-la dentro. (ACASO, 2011, p. 40).

Esta é uma reflexão que vem se tornando cada vez mais cara e necessária, reconhecermos que as imagens não são veículos inócuos, mas agentes culturais que performam os espectadores, que regulam suas subjetividades, identidades e identificações. A urgência desse reconhecimento de como agem as pedagogias culturais da imagem, passa pela responsabilidade e pelos papéis socioculturais das artes, das universidades, dos museus, das escolas. Conforme propõe os estudos e práticas da educação da cultura visual (MARTINS; TOURINHO, 2015), esse reconhecimento deve levar à articulação de estratégias pedagógicas para se trabalhar justamente nas brechas ou falhas dos sistemas socioculturais performativos das imagens. Conforme Butler (2012), nas práticas de repetição das normas performativas, nem todos os corpos fazem isso perfeitamente, da forma com a lei objetiva. Há excessos, subversões, incompletudes, discrepâncias e falhas entre as ações dos corpos e as normas. Nessas relações de repetição, atualização, negociação e resistência entre os corpos e as leis, emergem possibilidades de recontextualizar condições preestabelecidas e articular configurações culturais alternativas.

Nós, corpos, não somos meros depósitos de informações, conteúdos e imagens, ou, meros bonecos vodus predestinados e submetidos à manipulação e à arbitrariedade de leis inventadas por outros corpos. Compartilho da compreensão de corpomídia (KATZ; GREINER, 2005) a qual entende o corpo como contaminado e contaminador do ambiente, que recebe, reconstrói e coloca informações no mundo. As informações que chegam são transformadas em corpo, entram em contato com as que já estão, criando atritos, afeições e negociações. Essas trocas, que 
constituem as experiências do corpo, contribuem para a transformação do seu design, estrutura, percepção, movimento, formação, em termos biológicos e culturais. O corpo é o que vai se aprontando, é o resultado provisório das relações contínuas natureza-cultura. Corpo é processo, ação, trânsito entre natureza e cultura. Desse modo, o corpo pode ser visto como mídia desses processos, trocas e contaminações.

As imagens são performativas, elas têm um poder de transformação e não apenas de representação, no sentido de que elas (per)formam/(trans)formam a vida e as relações dos corposmídia. As imagens contaminam. Acreditando nas possibilidades dos corposmídia alargarem as brechas e falhas das normas reguladoras, e assim excederem, reconstruírem e ressignificarem imagens, informações e discursos, é que trabalhamos na perspectivada da dança contempop. O exercício criativo de elaborar movimentos com imagens de Frida passa por questionar-se sobre: o que diz a imagem? O que eu digo sobre a imagem? O que a imagem diz de mim? O que a imagem diz do contexto/momento onde vivo? Que experiências, acontecimentos, pessoas ela me faz recordar?

Discutindo como as normas reguladoras do sexo operam de uma maneira performativa para constituir a materialidade dos corpos, materializar o sexo do corpo, Butler (2012, p. 18, tradução do autor) argumenta que "a performatividade deve ser entendida não como um 'ato' singular e deliberado, mas, como a prática reiterativa e referencial mediante a qual o discurso produz os efeitos que nomeia". Numa espécie de redução interteórica (CHURCHLAND; CHURCHLAND, 1995), onde se desloca um conceito de uma área para outra, tenho tentado compreender essa engenhosidade da performatividade - realizar aquilo que nomeia - como estratégia de criação e como possibilidade de conceituação e compreensão da dança. Fazendo uma analogia, penso que Frida, em seu processo de criação, produzia imagens performativas. Sua pintura não representa sua realidade, mas a transforma, a excede; realiza ou reelabora a experiência vivida de outra forma.

Com Setenta (2008, p. 31-32), tenho buscando, junto a outros corpos, fazer-pensar uma dança performativa, ou seja, "um fazer-dizer que não apenas 'comunica' uma ideia, mas 'realiza' a própria mensagem que comunica", compreendendo "o corpo que dança como um inventor de modos próprios de proferir ideias". Propagadas pelos diferentes âmbitos da cultura pop e da arte, e trazidas pelos dançarinos para o processo de criação, as imagens de Frida passam por um crivo crítico, criativo e performativo. Buscamos configurar uma dança que não é representativa, mas performativa, ou seja, que não representa as imagens de Frida, mas as (trans)forma, as (per)forma - as realiza de outras formas. 
Investimos na possibilidade dos corpos subverterem seus referenciais, nesse caso, excederem as imagens de Frida, realizarem de outras formas aquilo - as imagens - a que se referem. O corpo se relaciona com a imagem encontrando estratégias para proferir a si próprio. Nesse sentido, não cabe entender como dança apenas os repertórios de movimentos prontos, habituais e já conhecidos, tão usados para comunicar e contar diferentes histórias. Nestas estratégias performativas está o desafio do corpo inventar modos próprios de fazer-dizer o que sente, pensa, quer, imagina, saindo do lugar comum de ser apenas veículo de uma mensagem, para ser, ele próprio - o corpo - mensagem. Conforme Setenta (2008, p. 45), "para produzir esse discurso só seu, o corpo trabalha experimentando/testando as informações, movimentando-as". Dança é corpo movendo ideias.

Nos processos criativos da dança contempop, compreendida como uma forma de dança performativa, os corpos atam, no fluxo de movimento, imagensartefatos, imagens-ideias, imagens-ações. Ao dançarem não há como distinguir com exatidão essas modalidades da imagem, dado que, o processo criativo conjunto de ações organizativas do corpo - é como um processador que mistura, atrela, amalgama artefato-ideia-ação. O que se dá a ver, a dança, é esse complexo de imagens, encharcadas de experiências, que deslizam no fluxo de movimento do corpo - seu autor, intérprete, criador.

Com a figura 03 é possível interpretar nuances performativas da dança contempop. São identificáveis algumas proximidades entre a imagem de referência (desenho Frida y el Aborto) e as imagens da coreografia. Também são perceptíveis modos como a imagem de referência foi excedida, subvertida, realizada de outras formas. Há elementos de Frida, tanto na estruturação do processo criativo que, como o dela, se vale das experiências dos corpos com as imagens, como na delimitação da escolha das imagens de referência pertencentes ou relacionadas ao universo pictórico dela. Todavia, em vez da representação ou da presença mais direta de dados biográficos, vestimentas ou acessórios característicos, estão ali fagulhas de uma possível saudade de Frida. Como se "ao sair alegre com o desejo de não voltar jamais", ela tivesse deixado a porta entreaberta, pegadas pintadas, marcas manchadas, lacunas lacônicas, e nós nos puséssemos a pintar preenchimentos nesses espaços afetivos com imagens-ações, com desenhos semoventes. Inspirados nos modos como Frida pintava a si própria, compondo um processo criativo que enredava arte, corpo e experiência, ousamos subverter e exceder normas e imagens performativas. 
Investimos numa dança performativa não para performar as ideias, os hábitos, as realidades dos corposmídia, materializando neles dogmas, morais e normas reguladoras. Em vez disso, uma dança performativa para performar com os corpos outras formas de ser e se mover, para articular com eles configurações culturais alternativas, subversivas e excedentes. Nesses fazeres, Frida tem sido: um conceito e contexto a ser estudado; uma imagem amiga e multifacetada a ser excedida; um corpo - natureza viva - a ser poeticamente exumado, contextualizado, sentido; um processo de criação artística a ser investigado.

No contexto da reflexão sobre como a fridomania pode ser vista como uma moda e como o conceito Frida Kahlo inclui e transcende a fridomania, Monsiváis (2004, p. 29, tradução do autor) afirma que "os artistas que utilizam Frida Kahlo podem ou não 'refuncionalizá-la' na perspectiva pós-moderna, ou usá-la como recurso intertextual." Reinterpretar e performativizar Frida nas perspectivas da estetização da cultura (AGUIRRE, 2011), das pós-produções na arte contemporânea (BORRIAUD, 2009), das pedagogias culturais (GIROUX, 1999), da educação da cultura visual (MARTINS; TOURINHO, 2015) e da dança contempop (BERTÉ, 2015) tem sido não só prazeroso como desafiador e instigante. De heroína a virgem dolorosa, Frida é uma imagem que, nos processos artísticos e pedagógicos que tenho participado e observado, tem estimulado corpos-estudantes à autoexpressão, à valorização de diferenças raciais, de gênero e orientação sexual, à reflexão sobre arte e política.

Romeromania, davincimania, riveramania, vangoghmania, michelangelomania, dalimania e tantas outras 'macho-arte-manias' existem e, ao que me parece, não tem sido tão questionadas como a fridomania. Ao seguir propondo Frida como imagem, assunto, processo a ser investigado, recriado e excedido, flerto com a fridomania sem quaisquer receio ou culpa perante as tradições artísticas. Estas tradições e seus dogmas movimentam altíssimos valores econômicos em torno do culto à obra de arte e insistem, hipocritamente, na contraposição arte $\mathrm{x}$ mercadoria. Desmerecem os artefatos que escapam ao seu controle, pois eles se tornam mais acessíveis, movimentam outras formas de venda, consumo, trocas, usos, reinvenções e experiências.

Reafirmo o desafio das artes, escolas, universidades, teatros, secretarias de cultura e museus assumirem um papel protagonista de compreenderem que são algumas entre tantas corporações e corpos a proliferar imagens. Como tais, têm importantes contribuições pedagógico-culturais a dar, não no sentido de demonizar o que tem Ihes escapado na enxurrada da estetização cultural para tentar reaver o poder e o controle perdido sobre tais artefatos e experiências. Mas, sim, no sentido 
de compreender e dialogar com os diferentes corpos e corporações que propagam imagens construindo formas de acesso mais democráticas aos discursos e imagens artísticas, interconectando e incorporando seus acervos ao cotidiano e experiências dos corpos, auxiliando-os a construir formas críticas, criativas e performativas de ver e se (mo)ver.

As manias e modas, consumos, usos e reinvenções fazem parte da constituição das experiências dos corpos com imagens, sejam elas de arte ou não. Depreciar essas experiências sob o peso do dogma proselitista que prega ser estética e verdadeira somente a experiência feita dentro dos templos da arte e perante as obras originais é no mínimo uma atitude medieval, arcaica e patriarcal sem quaisquer habilidades de contato com as realidades, os fenômenos e os corposmídia multifacetados e interconectados de hoje. Do lugar de onde faço-penso dança e o ensino de artes, a universidade, invisto em fazeres como a dança contempop que nada tem de messiânico, mas, sim, tem proposições de interações entre formas de ver e se mover, lidar com imagem e movimento nas interfaces entre as áreas da dança e da cultura visual. Nessas lidas, Frida segue sendo corpo, imagem, conceito, contexto e processo criativo que propõe, de modo (in)tenso, atravessamentos de arte, corpo e experiência - geradores de potentes redes para fazer-pensar processos criativos na contemporaneidade.

\section{Referências:}

ACASO, M. Del paradigma modernista al posmuseo: seis retos a partir del giro educativo (¿Lo intentamos?). In: ACASO, M. Perspectivas. Situación actual de la educación en los museos de artes visuales. Barcelona: Ariel, 2011. p. 36-43.

AGUIRRE, I. Cultura visual, política da estética e educação emancipadora. In: MARTINS, R.; TOURINHO, I. Educação da cultura visual: conceitos e contextos. 1 ed. Santa Maria: Editora UFSM, 2011. p. 69-111.

AUSTIN, J. L. Quando dizer é fazer: palavras e ação. Porto Alegre: Artes Médicas, 1990. $136 \mathrm{p}$.

BARTRA, E. Frida Kahlo en el siglo XXI. In: In: ORELLANA, M. Frida Kahlo, un homenaje. 1 ed. Ciudad de México: Fideicomiso Museo Dolores Olmedo y Fideicomiso Museos Diego Rivera - Frida Kahlo (Banco de México), 2004. p. 34-53.

BENJAMIN, W. A obra de arte na era de sua reprodutibilidade técnica. In: BENJAMIN, W. Magia e técnica, arte e política: ensaios sobre literatura e história da cultura. 8 ed. São Paulo: Brasiliense, 2012. p. 179-212.

BERTÉ, O. Dança Contempop: corpos, afetos e imagens (mo)vendo-se. Santa Maria, Ed. da UFSM, 2015. 200 p.

BERTÉ, O. Me Kahlo... Sashay Away. Espetáculo de Dança Contemporânea (50 min). Laboratório Investigativo de Criações Contemporâneas em Dança (LICCDA). Universidade Federal de Santa Maria. Santa Maria: 2015. 
BOURRIAUD, N. Pós-produção: como a arte reprograma o mundo contemporâneo. São Paulo: Martins, 2009. 112 p.

GIROUX, H. A cultura popular como pedagogia do Prazer e Significado: descolonizando o corpo. In: Giroux, H. Cruzando fronteiras do discurso: novas políticas em educação. Porto Alegre: Artmed, 1999. p. 211-240.

BUTLER, J. Cuerpos que importan: sobre los límites materiales y discursivos del sexo. Buenos Aires: Paidós, 2012. 346 p.

CHURCHLAND, Paul; CHURCHLAND, Patrícia. Intertheoric Reduction: a neuroscientist's field guide. In: Nature's Imagination. New York: Oxford University Press, 1995.

ESPECIAL Interkahlos. Direção e produção Anaqueli Rubin e Carine Provedello. Direção artística Odailso Berté. TV Campus e Laboratório Investigativo de Criações Contemporâneas em Dança (LICCDA). Universidade Federal de Santa Maria, 2016. (24 min.). Disponível em: <https://www.youtube.com/watch?v=NwY4q-M08OM). Acesso em: 11 set. 2016.

FERIDACALO. Intervenção de Dança. Direção de Odailso Berté. Criação do Laboratório Investigativo de Criações Contemporâneas em Dança (LICCDA). Curso de Dança - Licenciatura da Universidade Federal de Santa Maria (UFSM). Duração 60'. 2016.

FRIDA. Direção de Julie Taymor. Estados Unidos: Imagem Filmes. Miramax Internacional, 2002. 1 DVD (123 min.): DVD, NTSC, color.

FRIDA, naturaleza viva. Direção de Paul Leduc. México: Clasa Films Mundiales. Films Vintage, 1983. 1 DVD (110 min): DVD, NTSC-PAL, color.

GREINER, C. O corpo: pistas para estudos indisciplinares. 1 ed. São Paulo: Annablume, 2005. 152 p.

GUERREIRO, M. Uma conversa com Pina Bausch. Obscena: revista de artes performáticas, Lisboa: Perspectiva, n. 4, p. 60-69, mai. 2007.

HÉRCOLES, R. Corpo e Dramaturgia. In: NORA, S. (Org.). Húmus 1. Caxias do Sul: Prefeitura Municipal de Caxias do Sul - Secretaria da Cultura, 2006. p. 104-111.

HERRERA, H. Frida: a biografia. 4 ed. São Paulo: Globo, 2015. 624 p.

HOGUE, R. O teatro de Pina Bausch. Cadernos de Teatro, Rio de Janeiro: FUNDACEN, n. 116, p. 04-08, jan./fev./mar. 1988.

KAHLO, F. O diário de Frida Kahlo: um autorretrato íntimo. 4 ed. Rio de Janeiro: José Olympio, 2015. 282 p.

KAHLO, F. Raízes. Óleo sobre metal (30,5 x 49,9cm). 1943. Coleção privada, Houston.

KAHLO, F. La Columna Rota. Óleo / masonite $(39,8 \times 30,5 \mathrm{~cm})$. 1944. Coleção Museu Dolores Olmedo, Ciudad de México.

KAHLO, F. Sandías (Naturaleza muerta: Viva la vida). Óleo e terra sobre aglomerado (57 x $72 \mathrm{~cm}$ ). 1954. Coleção Museu Frida Kahlo, Ciudad de México.

KAHLO, F. La niña Virginia. Óleo / masonite $(78,5$ x $61 \mathrm{~cm}) .1929$. Coleção Museu Dolores Olmedo, Ciudad de México.

KAHLO, F. Retrato de Luther Burbank. Óleo / Masonite $(87$ x 62 cm). 1932. Coleção Museu Dolores Olmedo.

KAHLO. F. Unos cuantos piquetitos. Óleo / lamina (38 x 48,5 cm). 1935. Coleção Museu Dolores Olmedo, Ciudad de México.

Revista Digital do LAV - Santa Maria - vol. 9, n. 3, p. 60 - 85 - set./dez. 2016 ISSN 1983 - 7348 http://dx.doi.org/10.5902/1983734824044 
KAHLO, F. Mi nana y yo. Óleo / lamina $(30,5$ x 35 cm). 1937. Coleção Museu Dolores Olmedo, Ciudad de México.

KAHLO, F. Frida y el aborto. Litografia / papel (31,7 x 24 cm). 1932. Coleção Museu Dolores Olmedo, Ciudad de México.

KAHLO, I. P. Frida Íntima. 1 ed. Bogotá: Ediciones Dipon, 2004. 256 p.

KATZ, H.; GREINER, C. Por uma teoria do corpomídia. In: GREINER, C. O corpo: pistas para estudos indisciplinares. 1 ed. São Paulo: Annablume, 2005. p. 125-136.

LAKOFF, G.; JOHNSON, M. Philosophy in the flesh: the embodied mind and its challenge to western thought. New York: Basic Books, 1999. 626 p.

LAVÍN, M. Frida Kahlo: su obra los ojos de Frida. In: LARA, M. E. Museo Dolores Olmedo. Ciudad de México: Museu Dolores Olmedo Patiño, 2007. p. 200-241.

MARTINS, R.; TOURINHO, I. (Orgs.). Educação da cultura visual: aprender... pesquisar... ensinar... Santa Maria: Editora UFSM, 2015. 296 p.

MONSIVÁIS, C. De todas las Fridas posibles (una selección mínima). In: ORELLANA, M. Frida Kahlo, un homenaje. 1 ed. Ciudad de México: Fideicomiso Museo Dolores Olmedo y Fideicomiso Museos Diego Rivera - Frida Kahlo (Banco de México), 2004. p. 08-33.

RICO, A. Frida Kahlo: fantasia de um cuerpo herido. 3 ed. Cuidad de México: Plaza y Valdés, 2004. 181 p.

SETENTA, J. S. O fazer-dizer do corpo: dança e performatividade. 1 ed. Salvador: EDUFBA, 2008. 124 p.

ZAMORA, M. Cartas apaixonadas de Frida Kahlo. 4 ed. Rio de Janeiro: José Olympio, 2006. 160 p.

\footnotetext{
i Professor do Curso de Dança - Licenciatura - UFSM; Doutor em Arte e Cultura Visual - UFG; Mestre em Dança - UFBA; Especialista em Dança - FAP; Licenciado em Filosofia - UPF; Coordenador do Laboratório Investigativo de Criações Contemporâneas em Dança - LICCDA.
}

Enviado em: 18 de outubro de 2016.

Aprovado em: 01 de dezembro de 2016. 